\title{
The Inclusion of Cultural Elements in College Japanese Teaching
}

\author{
Wang Shanshan \\ Foreign Language Department \\ Jilin Business and Technology College \\ Changchun, China \\ 182076127@qq.com
}

\begin{abstract}
Language learning is not an isolated progress, since every language is closely associated with its social culture and background. Therefore, in Japanese teaching, we not only need to explain Japanese grammar, train the students to use it, but also need to introduce Japanese social culture and background knowledge. Due to its special ethnic character, its historical complications and its particular geographical environment, Japan has evolved its unique culture. So the introduction of Japanese culture knowledge is very important in Japanese teaching course. This paper aims to confirm the feasibility of including cultural elements in college Japanese teaching and explore corresponding strategies to include cultural knowledge in college Japanese teaching. On the basis of discussing the relationship between culture and language, the paper makes an in-depth analysis of cultural inclusion in Japanese teaching through summarizing the distribution of cultural information in Japanese textbooks. At last, three strategies are proposed respectively to infiltrate Japanese social and cultural knowledge to Japanese teaching. This paper bases the research on practice, namely the distribution of cultural information in college Japanese textbooks, which is of practical significance.
\end{abstract}

Keywords-language; culture; Japanese teaching; social culture; guiding

Someone said: "it is easy to learn Japanese because we can roughly know the meaning through analyzing the Chinese characters in the Japanese sentence”, but it not absolutely true. Although Japanese is highly affected by Chinese, lying in the source of the letters in Japanese imitating the component canopy or cursive script of Chinese characters, after a long period of evolution, Japanese has turned into a completely different and independent language. Any language is in the use of people who live in a certain context to achieve mutual communication through spoken or written language form. At the same time, a particular language is always associated with the nationality or the country in use of it and related to historical, cultural and social backgrounds. Because of cultural differences between two countries, the same word in Japanese and Chinese doesn' t necessarily refer to the same thing. The word “娘” ,for example, means “mother” in Chinese, but in Japanese, refers to “daughter or girl” , the word “娘” has totally different meanings in Chinese and Japanese. For another, the word “学生” refers to anyone studying in elementary school, middle school and college, but means especially “college students" in Japanese. The word “手纸” refers to "toilet paper or sanitary paper" in Chinese, but means "letters" in Japanese[1].

\section{The Relationship BetweEn LANGUAgE AND CULtURE}

Cultural linguists believe that the relationship between language and culture is close, which play mutual roles and exert mutual influence on each other. On the one hand, language is the foundation of culture, which is a record of cultural symbols and is the important carrier of culture. On the other hand, culture is the power of language creation and expression, whose content restricts the production and the development direction of language, so that national language possesses its own cultural characteristics and forms the characteristics different from other languages. It can be explained from the following aspects.

(1)Language is the most common and important tool people communicate with in social life. Since each society has its specific culture, language that social members use in communication inevitably reflects its culture, so far as to say that "to a great extent, language is the product of culture and culture and language are inseparable.”

(2) Like other ethnic languages, Japanese, in the process of its formation and development, whose culture plays a decisive role in guidance and restriction, must be learnt in the way to reflect Japanese culture. From the relationship between language and society, language is a social phenomenon, whose essential attribute is a social communication tool, which suggests there is a close relationship between language and society. Language emerges with the appearance of society and develops with development of society, which determines that language should be used in the restriction of society, because when people use language for communication, they must comply with the established norms of society. Therefore, it is a major topic of the current foreign language teaching to conduct a further study on the social and cultural factors in language and the conscious cultivation of a cultural insight.

(3) As is known, culture has a broad connotation. Culture is, in the words of E.B. Tylor, "that complex whole which includes knowledge, belief, art, morals, law, custom and any other capabilities and habits acquired by man as a member of society." Alternatively, in a contemporary variant, "Culture is defined as a social domain that emphasizes the practices, 
discourses, and material expressions, which, over time, express the continuities and discontinuities of social meaning of a life held in common."[2] Language is an important part of culture and different cultures reflect the similarity or dissimilarity culture. Goodnough in Cultural anthropology and Linguistics pointed out "the language of a society is one aspect of the social culture, whose characteristic is reflected as 'it is the main tool of learning culture, people in the process of study and the use of language can gradually obtain whole culture."'[3] Each nation has its own culture, which forms in the specific natural environment, historical conditions and social realities and has its own particularity.

It is obvious that the relationship between language and culture is very close, no exception of Japanese. To learn Japanese well, it is necessary to understand Japanese social culture and habits.

\section{The NECESSITY TO INCLUdE JAPANESE CULTURE IN COLLEGE JAPANESE TEACHING}

Different countries have different language, culture and customs, and each language reflects a particular culture, so any form of language has a certain cultural connotation. Without understanding the social culture of a language, it is impossible to correctly understand and use the language. For example, when Chinese people meet, they tend to ask "Where are you going?” or "Have you eaten?”, which doesn't necessarily mean to know whether the other one really wants to go anywhere or eat anything but is just a way of greeting. When Japanese people meet with each other, they tend to say “こんにちは! いいお天気ですね.” (Hello! It’ s a fine day today! ) or “よく降りますね.” (It’ s always raining! ), mostly to talk about good weather condition. Although they ask “どちら $\sim$ ?" (Where are you going), the other one simply respond with “ちょっとそこまで.” (I am going there.) [4] For another, making a phone call is also a matter of language habits. When Chinese people answer a phone call, they often ask

"Hey, who are you?" or "Whom do you want to talk to?", but when Japanese people answer a phone call, they often tell the other one their name or unit and then talk. In addition, Chinese don't pay particular attention to their speech and act during having a meal. If there is a guest having dinner together, the host tends to let the guest start eating first, but on Japanese dining table, a guest first says “いただきます.” (Sorry, I begin to take it now). After the dinner, the guest says “ごち そうさまでした!” (Thanks for your hospitality!), or he will be considered rude[5].

Although China and Japan are both influenced by the thought of Confucianism, Taoism and Buddhism, there exists an obvious difference in culture between the mainland and the island. Japan's special geographical location, clear seasons, mild climate and terrain conditions have raised the Japanese nation and created the basic character, ideas and aesthetic temperament and interest of Japanese, love, affinity, and advocating nature, which have become the important foundation of Japanese culture. For the introduction of foreign culture, Japan belongs to the type to actively absorb, the Meiji government put forward the policy of the civilization, the active introduction of European and American culture at the same time of the transformation of Confucianism, Shinto and Buddhism, striving to make the European culture fusing with the culture of the three religions, which has formed the unique modern culture of Japan. In addition, in the process of the absorption of foreign culture, Japan has gradually established a culture mode of conflict, coexistence and fusion, making the Japanese people judge things with a relatively eclectic attitude, thus forming national consciousness on the basis of "harmoniousness", which is throughout all fields of Japanese culture, ideology, psychology and life and is as well as performed on the concept of language and its structure. China, to the opposite, belongs to the type to negatively intake because China's culture stays in a superior position for a long time [6]. As a civilization center, it has been radiated to the surrounding countries, so Chinese people are proud of China's excellent cultural tradition and stay in the closed state for a long time. Thus, social and cultural relations between the two countries have in common, but the great differences are also reflected in many aspects. In Japanese teaching, therefore, it is necessary to include the culture interpretation, so that college students in learning Japanese, on the basis of Japanese culture, will get twice the result with half the effort.

\section{ThE INCLUSION OF JAPANESE CULTURE IN JAPANESE TEACHING}

In actual Japanese teaching process, traditional grammar translation method and structure analysis method are still used by the teacher whose emphasis is put on imparting knowledge. Japanese teachers generally adopt vocabulary and grammar analysis and sentence pattern practice, but this teaching mode attaches too much importance to Japanese grammar structure analysis and only puts emphasis on mastery of the three elements of phonetics, vocabulary and grammar. If teachers spare most efforts in the analysis of Japanese sentence patterns and grammar and the interpretation of article reading and examination skills, context and pragmatics are ignored at the same time, which is bound to students' incapability in nonverbal behavior, cultural identification and intercultural communication. Thus, students, in the process of the actual communication, lack of ability to apply appropriate language in appropriate places, that is to say, they're often incapable to use Japanese flexibly according to occasion, or even use verbal communication standard of Chinese culture to use Japanese, making a joke and causing communication failure at last. In addition, students often mechanically read sentences when practicing sentence patterns and also ignore the nonverbal behavior of communication, such as body gesture and facial expression, which will naturally cause students to leave bad impression on the other person in the process of communication. For example, Japanese people pay close attention to the "bowing" and use the body gesture whenever they meet others at first time or they greet others in daily life. The best way to admit a mistake is also to bow. In addition, Japanese, when saying goodbye to the other one, in addition to constantly bowing, will also say some words to show politeness in order to keep the cement and friendly relations between each other. Bowing is also known as a sign of well-educated and polite performance. In this aspect, students’ performance of this gesture differs largely from local 
Japanese in that they bow inflexibly and unharmoniously. In in the process of teaching Japanese culture, teacher only delivers Japanese literature, art, music, history, geography, humanities and cultural knowledge to students, while ignoring cultural knowledge teaching including Japan communication habits, social customs, practice of life and so on, which leads to students' partial understanding of Japanese culture. Their knowledge of Japanese culture is mostly confined to the understanding of Japanese traditional arts or crafts, attaching Japanese culture to cherry blossoms, tea ceremony and bushido, so that students will lack of awareness of cultural differences between China and Japan. In the process of Japanese communication, students will measure the culture of Japan unconsciously according to China's cultural standards and way of thinking, and thus lead to the failure of communication. In Japanese teaching, although students have mastered knowledge of Japanese and reached the level of the five basic skills in listening, speaking, reading, writing and translating according to the requirements of teaching outline, they often cause misunderstanding when communicating in the practical applications, because they don't understand the Japanese social and cultural knowledge. So, students, in the process of learning Japanese, should not only learn the basic language knowledge of Japanese in terms of pronunciation, vocabulary, syntax and so on, but also become familiar with Japanese society and culture, only in this way can they use Japanese properly and correctly and improve the ability of intercultural communication.

The author thinks that the cultural components in the teaching material appear in different levels and are embedded in discourse in different ways. The obvious pragmatic habits, patterns and unique cultural images are known as "dominant cultural information”. On the contrary, social background and national consciousness hidden in the text belong to "recessive culture information". The "dominant cultural information" and the "recessive culture information" combine the cultural information in the teaching material. After analyzing the cultural information in the textbooks of New Japanese and Standard Japanese, this paper summarizes the cultural information in Table 1.

TABLE I. DISTRIBUTION OF CULTURAL INFORMATION IN JAPANESE TEXTBOOKS

\begin{tabular}{|l|l|}
\hline \multicolumn{1}{|c|}{ Dominant cultural information } & \multicolumn{1}{|c|}{ Recessive culture information } \\
\hline $\begin{array}{l}\text { (1)Vocabulary idioms, allusions, } \\
\text { idioms, slang, proverbs, industry } \\
\text { words, dialect words, etc. }\end{array}$ & $\begin{array}{l}\text { (1)The omitted common background } \\
\text { knowledge, values, ways of thinking } \\
\text { and social norms in the discourse of } \\
\text { cultural background. }\end{array}$ \\
$\begin{array}{l}\text { (2)Grammar word-formation, word } \\
\text { order, sentence structure, etc. }\end{array}$ & $\begin{array}{l}\text { (2)The superficial meaning of words } \\
\text { with additional cultural meaning and } \\
\text { (3)Rhetoric metaphor, pun, habit of } \\
\text { expression, etc. } \\
\text { (4)Cultural image, such as Momotaro meaning (such as color, } \\
\text { in Japanese. }\end{array}$ \\
& $\begin{array}{l}\text { number and name, reflecting } \\
\text { difference in additional cultural } \\
\text { meaning between Chinese and } \\
\text { Japanese.) } \\
\text { (3)Non-language factors' different }\end{array}$ \\
& $\begin{array}{l}\text { rules of behavior, emotional } \\
\text { expression, communication habits, } \\
\text { etc. }\end{array}$ \\
\hline
\end{tabular}

\section{StRATEgIES TO INCLUdE CUltural KNOWLEDGE IN COLLEGE JAPANESE TEACHING}

In order to infiltrate Japanese social and cultural knowledge to Japanese teaching, first of all, teachers must understand the social and cultural differences between Japanese and Chinese. Teachers not only provide students with Japanese culture information, but also guide students to use correct expressions in different situations and try to help students avoid using Chinese standard to measure the Japanese culture, helping students obtain a kind of cross-cultural consciousness as soon as possible. Secondly, through the following channels, Japanese social and cultural knowledge can be included into college Japanese teaching.

First, the selected teaching material must be original. In the primary stage of teaching, teachers should choose a certain percentage of the original Japanese textbooks. These materials involve Japanese cultural background, customs and habits, etc. Simple dialogue can involve all aspects of the Japanese culture, because the speakers all comply with the rules of cultural behavior and the dialogue expresses their formal response. With the teaching material, teachers should get down to the interpretation of cultural knowledge purposefully.

Second, students can intend to accumulate information about Japanese cultural background, social customs, social relations and related cultural knowledge by reading literary works, newspapers and magazines. College teachers should also encourage students to devote to a large amount of extracurricular reading, especially reading famous Japanese literature, which is also a kind of important means to learn about Japanese culture. Because literary works of a nation are the essence part of national culture, the accumulation of traditional culture and one of the most vivid and abundant materials to understand the character, the inner world, cultural background, customs and habits, social communication of a nation. In addition, reading online is also the most direct and efficient way to help students get access to Japan's latest information and understand Japan's current social dynamics, social problems and social relations. This kind of information is not involved in the textbooks.

Third, the electronic, audio-visual and other teaching methods can be used to let the students watch pictures, videos or films that can reflect Japan's various aspects and forms of culture, causing college students to have an intuitive understanding of the local conditions, customs, interpersonal relationship, ways of thinking and other social and cultural knowledge of the Japanese society.

At last, teachers in spare time can carry out various forms of activities, such as holding Japanese seminar, Japanese corner, Japanese debate and Japanese sketch, etc., creating artificial environment for Japanese study and stimulate students' interest in learning Japanese, thus, they are able to have a more profound understanding of the cultural knowledge from these specific forms.

\section{CONCLUSION}

In short, college Japanese teaching should attach importance to the cultural difference between China and Japan 
and should understand the difference. College Japanese teachers should not only help students learn language, but also help students understand Japanese social and cultural knowledge in various forms. Only in this way can students learn Japanese language knowledge and cultural knowledge at the same time, constantly enrich and expand their knowledge of Japanese, enhance their sensitivity of Japanese national culture and avoid some pragmatic errors due to cultural difference, so as to correctly use Japanese in cross-cultural communication.

\section{REFERENCES}

[1] Jia Yuxin. Intercultural communication[M]. Shanghai: Shanghai Foreign Language Education Press,1997.

[2] Wang Fuxiang, Wu Hanying. Language and culture[M]. Beijing: Foreign Language Teaching and Research Press, 1994.

[3] Gu Jiazu. Cross-cultural communication: the covert culture in foreign language literature[M].Nanjing : Nanjing Normal University Press, 2000.

[4] Shu Dingfang, Zhuang Zhixiang. Modern foreign language teaching: theories, practice and methods[M]. Shanghai: Shanghai Foreign Language Education Press,1996.

[5] Wu Ting. The importance of cultural introduction to foreign language teaching class[J]. Japanese Study and Research,2000(1).

[6] Xiao Xia. Improve teaching methods and the level of college Japanese teaching $[\mathrm{A}]$. The 21st century education research on Japanese language[M]. Jilin People’s Press, 2004. 